Article

\title{
Associations between Milk and Dairy Product Intake, Urinary Sodium-to-Potassium Ratio, and Socioeconomic Status in Japanese Male Adolescents
}

\author{
Yosuke Nagashima ${ }^{1, *(D)}$, Akiko Horikawa ${ }^{2}$, Ayana Mitsume ${ }^{1}$ and Mari Mori ${ }^{3}$ \\ 1 Department of Health Science, Musashigaoka Junior College, 111-1 Minamiyoshimi, \\ Yoshimi 355-0154, Saitama, Japan; mitsume-a@musashigaoka.ac.jp \\ 2 Department of Sport Science, School of Human and Social Sciences, Tokyo International University, \\ 2509 Matoba, Kawagoe 350-1198, Saitama, Japan; akhorika@tiu.ac.jp \\ 3 Department of Health Management, School of Health Studies, Tokai University, 4-1-1 Kitakaname, \\ Hiratsuka 259-1292, Kanagawa, Japan; m_mori@tsc.u-tokai.ac.jp \\ * Correspondence: nagashima-y@musashigaoka.ac.jp; Tel.: +81-493-54-5101
}

Citation: Nagashima, Y.; Horikawa, A. Mitsume, A.; Mori, M. Associations between Milk and Dairy Product Intake, Urinary Sodium-to-Potassium Ratio, and Socioeconomic Status in Japanese Male Adolescents. Adolescents 2022, 2, 73-85. https:// doi.org/10.3390/adolescents2010008

Academic Editor: Laura L. Hayman

Received: 27 December 2021

Accepted: 10 February 2022

Published: 18 February 2022

Publisher's Note: MDPI stays neutral with regard to jurisdictional claims in published maps and institutional affiliations.

Copyright: (C) 2022 by the authors. Licensee MDPI, Basel, Switzerland. This article is an open access article distributed under the terms and conditions of the Creative Commons Attribution (CC BY) license (https:// creativecommons.org/licenses/by/ $4.0 /)$.

\begin{abstract}
Although socioeconomic status (SES) may affect children's urinary electrolytic excretion and dietary intakes, few studies have reported the association between SES and urinary sodium $(\mathrm{Na})$-to-potassium $(\mathrm{K})$ ratio in Japanese adolescents and children. Therefore, this study aimed to investigate the association between SES and urinary $\mathrm{Na} / \mathrm{K}$ ratio (Analysis 1 ) and between dietary intake and urinary $\mathrm{Na} / \mathrm{K}$ ratio to determine the SES effects in children and adolescents (Analysis 2). This cross-sectional study included 168 Japanese male adolescent and child football players. The urinary $\mathrm{Na} / \mathrm{K}$ ratio was calculated from three spot urinary electrolyte values. Multiple regression analysis was performed in both first and second analyses to assess the associations between SES and the urinary $\mathrm{Na} / \mathrm{K}$ ratio and between dietary intake and the urinary $\mathrm{Na} / \mathrm{K}$ ratio for ages 9-12 and 13-15 years separately. The mean urinary $\mathrm{Na} / \mathrm{K}$ ratio was 4.8 , with higher $\mathrm{SES}$ associated with a lower urinary $\mathrm{Na} / \mathrm{K}$ ratio. Our results suggested that urinary $\mathrm{Na} / \mathrm{K}$ ratios in Japanese child football players were high due to poor childhood diets, and higher SES was associated with lower urinary $\mathrm{Na} / \mathrm{K}$ ratios. Further, milk and dairy products are associated with the urinary $\mathrm{Na} / \mathrm{K}$ ratio, independent of SES in children and adolescents.
\end{abstract}

Keywords: cardiovascular diseases; adolescents and children; urinary sodium-to-potassium ratio; dietary intake; socioeconomic status

\section{Introduction}

High sodium intake is a risk factor for hypertension, a condition associated with cardiovascular diseases (CVDs) in adults, whereas low sodium and high potassium intakes can reduce blood pressure [1,2] and CVD risk [3,4]. The relationship between sodium and blood pressure strengthens if the urinary sodium-to-potassium $(\mathrm{Na} / \mathrm{K})$ ratio is considered, instead of sodium excretion rate alone [5]. Therefore, determining the factors influencing sodium and potassium intake may help prevent hypertension occurrence in the future. Previous studies have demonstrated high urinary sodium levels among Japanese children and adolescents [6,7]. Salt intake during childhood was associated with high blood pressure in later life [8], which very likely increases the future risk of adult hypertension and subsequent CVDs.

Previous studies have reported that individuals with a lower socioeconomic status (SES) - a lower income, lower educational attainment, and manual occupations-had higher salt intake [9-12]. They also assessed sodium intake using a questionnaire or through a 24 h dietary recall, which may be less accurate than actual measurements. Although repeated measurements of sodium excretion in the urine over $24 \mathrm{~h}$ are regarded 
as the gold standard [6,13], $24 \mathrm{~h}$ urine sampling could not be easily adapted for some population groups, such as very young children [14]. Therefore, spot urine was developed, which has been used to obtain representative values for a population. Previous studies reported relationships between the urinary $\mathrm{Na} / \mathrm{K}$ ratio in casual urine samples with blood pressure levels [14]. Further, a recent study demonstrated that spot urine collection was used to estimate the average individual-level sodium intake and found that the accuracy of estimates increased with the addition of extra samples [15].

SES has been associated with higher sodium intake in various populations [16-18]. Using urinary samples in the previous two studies showed that SES factors were associated with a lower potassium intake and higher spot urinary $\mathrm{Na} / \mathrm{K}$ ratio in Japanese adults $[18,19]$. However, only a few reports have demonstrated the association between urinary $\mathrm{Na} / \mathrm{K}$ ratio and dietary intake in Japanese children [19]. Although SES affects dietary intake, no study has considered its effect to the best of our knowledge.

Our previous study reported that the urinary $\mathrm{Na} / \mathrm{K}$ ratio was high in Japanese adolescent football players [7]. Globally, the number of studies using urinary sodium and potassium excretion in children has increased $[16,20]$. Understanding the urinary excretion of sodium and potassium in children, including athletes, is important for approaches toward child health issues. Further, Seko et al. [17] reported that eating habits during childhood are disturbed; therefore, children and adolescents should be understood separately because of their different psychological and psychosocial stages of maturation and diverse social influences that may affect their dietary intake.

Therefore, it was hypothesized that SES is associated with the urinary $\mathrm{Na} / \mathrm{K}$ ratio and dietary intake, by conducting two study analyses. The first analysis aimed to clarify the association between SES and the urinary $\mathrm{Na} / \mathrm{K}$ ratio and dietary intake by age group. The second analysis aimed to clarify the food groups associated with urinary $\mathrm{Na} / \mathrm{K}$ ratio and to examine the effects of SES on them.

\section{Materials and Methods}

\subsection{Participants}

This was a cross-sectional study that recruited 164 healthy Japanese male adolescent (13-15 years) and child (9-12 years) football players from November to December 2020 from a football team in central Saitama, Japan, and 158 of them agreed to participate (response rate, $96.3 \%$ ). Healthy Japanese male adolescent and child football players (9-15 years) and players with high physical activity were eligible. The selection criteria were advanced training levels, following the NSCA standards [21]. To meet the advanced training level according to the NSCA, participants should have a training age of $\geq 1$ year and training frequency of $\geq 3-4$ days per week.

Participants did not undergo dietary management for weight gain or loss. Since previous studies reported that adolescents from single-parent families have lower healthpattern scores than those from two-parent families, we excluded adolescents from singleparent families from this study [22]. Among the total 158 included participants, 20 were excluded from the analyses ( 2 withdrew consent, 5 had extremely unrealistic energy intake, 4 did not submit urine collections, 1 was a single-parent family, and 8 had missing data). In total, 138 participants (84.1\%) were ultimately included in the analysis. This study was conducted following the guidelines stipulated in the Declaration of Helsinki, and all procedures were approved by the Ethics Committee of Musashigaoka Junior College, Japan (No. 20-3). Written informed consent was obtained from all participants and their parents.

\subsection{Socioeconomic Status}

In this study, the obtained highest parental educational status was used to define the SES of participants. Although SES typically includes income, educational status, wealth status, and employment type, a Japanese cohort study showed that although the educational level was significantly associated with systolic blood pressure, diastolic blood pressure, 
and prevalence of hypertension, household income levels were not associated with these outcomes [20]. Therefore, we used the parental educational status.

Parental educational status was obtained using a self-administered questionnaire. The classification of educational subgroups is based on the International Standard Classification of Education (ISCED) [23]: "Low" educational status corresponds to end of compulsory education ( $\leq 11$ years, ISCED levels 1 and 2$)$; "middle" educational status corresponds to at least 3 years of additional schooling (12-15 years, ISCED levels 3 and 4); and "high" educational status corresponds to a Bachelor's degree or higher $(\geq 16$ years, ISCED levels 5 and 6).

\subsection{Spot Urine Collection}

Three-spot urine collection was conducted to estimate the daily urinary $\mathrm{Na} / \mathrm{K}$ ratio. Recent studies have demonstrated that the method of estimating daily urinary $\mathrm{Na} / \mathrm{K}$ ratio and urinary sodium excretion using multiple-time spot urine on different days is a substitute for 2-day $24 \mathrm{~h}$ urine collection [15]. The mean sodium excretion by the simple mean method with three spot urine samples was closest to that by $24 \mathrm{~h}$ collection, with the accuracy of estimates increased with the addition of extra spot urine samples, which concorded with correlation cosecants of 0.20 (one-spot urine sample), 0.31 (two-spot urine samples), and 0.42 (three-spot urine samples) [24]. From the above, we had collected spot urine three times to evaluate the urinary $\mathrm{Na} / \mathrm{K}$ ratio in this study.

In advance, each participant received an instruction sheet on how to collect urine. The participants were provided with three $10 \mathrm{~mL}$ tubes to confirm the urine collection procedure. Urine sampling was conducted from 20 to 27 December 2020. During this period, the three-spot samplings had intervals of $>1$ day between them. They were collected at 2 school days and 1 non-school day (i.e., weekends, public holidays, and school holidays). Spot urine collections were not performed on days marked by sickness or vigorous sporting activity; urine collections were held on days without practice or participation in a match. The first-morning urine was obtained as the spot urine (first voiding after rising).

After completing a spot urine collection, participants submitted their urine samples at Musashigaoka Junior College. All specimens were kept refrigerated and sent to SRL Corporation (SRL, Tokyo, Japan). Urinary sodium (mmol/L) and potassium (mmol/L) levels were analyzed using a selective ion electrode method. The urinary $\mathrm{Na} / \mathrm{K}$ ratio was also calculated as urinary sodium $(\mathrm{mmol} / \mathrm{L})$ divided by urinary potassium $(\mathrm{mmol} / \mathrm{L})$. The mean value of the three spot urine samples was used as the analysis value. The interclass correlation coefficient $(1,3)$ for the mean value reliability of three spot urine samples was $0.732(0.708-0.756)$.

\subsection{Dietary Assessment}

Dietary intake was obtained using the self-administered dietary history questionnaire (DHQ), which was conducted 1-3 days before anthropometric measurements. Details of the structured DHQ and calculation method of dietary intake have been published elsewhere $[25,26]$. Briefly, the DHQ is a 22-page structured questionnaire comprising questions regarding the consumption frequency and portion size of selected foods commonly consumed in Japan, general dietary behaviors, and usual cooking methods [27]. Estimates of daily food, energy, and nutrient intakes were calculated using an ad hoc computer algorithm for the DHQ based on the Standard Tables of Food Composition in Japan [28]. The response method, portion size, and amount of school lunch in detail were explained to participants and their mothers in a $60 \mathrm{~min}$ briefing session by trained researchers. All DHQs were sent to a DHQ Support Center (Gender Medical Research, Tokyo, Japan). Nutritional and food intakes were calculated using a dedicated nutritional calculation program.

Our previous study in adolescent athletes verified the validity of DHQ using a 3-day dietary record (DR), and the median correlation coefficient between DHQ and DR is 0.36 for 13 items of energy and nutrient intakes and 0.30 for 13 items of food intake [29]. In this study, nutrient intakes of 6 items $(r=0.35-0.55)$ and the food intake of 7 items $(r=0.30-0.53)$ were 
used for analyses, and have been reported to have a moderate or higher rank correlation in previous studies.

\subsection{Other Variables}

Anthropometry was performed on the submission day of urine collection and DHQ. Body height was measured using a stadiometer (YHS-200D, YAGAMI Inc., Nagoya, Japan). Body mass and body fat percentage were measured using bioelectrical impedance analysis (In Body 470, Bio Space Inc., Seoul, Korea). Body height (to the nearest $0.1 \mathrm{~cm}$ ), body mass (to the nearest $0.1 \mathrm{~kg}$ ), and body fat percentage (to the nearest $0.1 \%$ ) were measured while wearing lightweight indoor clothes only without shoes. Body mass index (BMI; $\left.\mathrm{kg} / \mathrm{m}^{2}\right)$ was calculated as the body mass $[\mathrm{kg}] /$ body height $\left[\mathrm{m}^{2}\right]$. Fat-free mass $(\mathrm{kg})$ was calculated as body mass $(\mathrm{kg})$ - body mass $(\mathrm{kg}) \times($ body fat percentage $(\%) / 100)$. The Fat-Free Mass Index was calculated as the fat-free mass $(\mathrm{kg}) /$ body height $\left(\mathrm{m}^{2}\right)$. The investigator measured the blood pressure using an automatic digital monitor (Omron HEM-757 Omron Corp, Tokyo, Japan) and using a standardized, automated measurement system after the participants were allowed to sit/rest for $5 \mathrm{~min}$. The mean of two readings was used for analysis.

Age, family size, sports activities, and TV or video watching were obtained using a self-administered questionnaire. Physical activity was computed from three activities (vigorous activities, walking, and standing activities) using the DHQ.

\subsection{Statistical Analysis}

All statistical analyses were performed using JMP version 14.3.0. (SAS Institute Inc., Cary, NC, USA). Continuous variables are expressed as the mean \pm standard deviation, and categorical variables are assessed as counts and percentages. The normality of data was assessed using the Shapiro-Wilk test. Considering the different dietary habits between age groups, a separate analysis was performed in participants aged 9-12 and 13-15 years. The income in the high-education group was reportedly higher than that in the middle group [30]. Since the number of people in the low-education group in Japan was not that large, this study, therefore, analyzed two groups: high and middle/low.

In Analysis 1, we investigated whether SES was associated with the urinary $\mathrm{Na} / \mathrm{K}$ ratio. To compare the difference in the mean urinary $\mathrm{Na} / \mathrm{K}$ ratio according to SES, a one-way analysis of variance was performed. After that, multiple regression analysis was carried out to assess whether or not SES was associated with the urinary $\mathrm{Na} / \mathrm{K}$ ratio by age group. The dependent variable was SES, and the independent variable was the urinary $\mathrm{Na} / \mathrm{K}$ ratio. The potential confounding factor was BMI. Unadjusted models and models adjusted for BMI were used. The high-SES group was entered as an indicator variable into the model with the low-and-middle-SES group acting as the reference group.

In Analysis 2, food groups related to the urinary $\mathrm{Na} / \mathrm{K}$ ratio were investigated, and then, when considering the effects of SES, the independent association between dietary intake and urinary $\mathrm{Na} / \mathrm{K}$ ratio was also examined. To evaluate whether SES is a confounding factor in the association between dietary intake and the urinary $\mathrm{Na} / \mathrm{K}$ ratio, the difference in the mean dietary intake was compared according to SES using one-way analysis of variance. SES was considered a potential confounding factor. Consequently, dietary intake independently associated with the urinary $\mathrm{Na} / \mathrm{K}$ ratio was examined by multiple regression analysis considered for BMI and SES. The dependent variable was the urinary $\mathrm{Na} / \mathrm{K}$ ratio, the independent variable was the food group, and the independent variable selection was calculated using a stepwise method; the confounding variables were BMI and SES. We present unadjusted models (Model 1), a model adjusted for BMI based on age group (Model 2), and a model adjusted for BMI and SES based on age group (Model 3). The standardized regression coefficient $(\beta)$ and corresponding $p$-values are presented. All reported $p$-values were two-tailed, and $p$-values $<0.05$ were considered statistically significant. 


\section{Results}

Table 1 shows the basic characteristics of study participants. Age 13-15 years accounted for $63.8 \%$ of participants and $9-12$ accounted $36.2 \%$, and the cohort had the following mean values: age, $12.7 \pm 1.7$ years; TV or video watching, $4.4 \pm 2.1$; duration of sports activities, $20.7 \pm 4.9 \mathrm{~h} /$ week; BMI, $18.4 \pm 2.1 \mathrm{~kg} / \mathrm{m}^{2}$; body fat percentage, $13.1 \pm 4.8 \%$; systolic blood pressure, $120.7 \pm 13.8 \mathrm{mmHg}$; and diastolic blood pressure, $67.6 \pm 10.0 \mathrm{mmHg}$. SES was high in $45.7 \%$ of the participants.

Table 1. Basic characteristics of the study participants.

\begin{tabular}{|c|c|c|}
\hline \multirow{2}{*}{ Variable } & \multicolumn{2}{|c|}{ Total Sample $(n=138)$} \\
\hline & Mean & SD \\
\hline Age, years & 12.7 & 1.7 \\
\hline \multicolumn{3}{|l|}{ Age group, $n(\%)$} \\
\hline $9-12$ years & \multicolumn{2}{|c|}{$50(36.2)$} \\
\hline $13-15$ years & \multicolumn{2}{|c|}{$88(63.8)$} \\
\hline Physical activity level, $n(\%)^{\text {a }}$ & & \\
\hline Level III (high) & \multicolumn{2}{|c|}{$27(19.6)$} \\
\hline Level IV (very high) & \multicolumn{2}{|c|}{$111(80.4)$} \\
\hline Sports activities, $\mathrm{h} /$ week & 20.7 & 4.9 \\
\hline Family size & & \\
\hline Nuclear family & \multicolumn{2}{|c|}{$117(84.8)$} \\
\hline Extended family & \multicolumn{2}{|c|}{$21(15.2)$} \\
\hline TV or video watching, $\mathrm{h} /$ week & 4.4 & 2.1 \\
\hline Body height, $\mathrm{cm}$ & 156.3 & 11.9 \\
\hline Body mass, $\mathrm{kg}$ & 45.7 & 10.4 \\
\hline BMI, $\mathrm{kg} / \mathrm{m}^{2}$ & 18.4 & 2.1 \\
\hline Body fat percentage, $\%$ & 13.1 & 4.8 \\
\hline Fat-free mass, kg & 39.7 & 9.1 \\
\hline FFMI, $\mathrm{kg} / \mathrm{m}^{2}$ & 16.0 & 1.7 \\
\hline Systolic blood pressure, $\mathrm{mmHg}$ & 120.7 & 13.8 \\
\hline Diastolic blood pressure, $\mathrm{mmHg}$ & 67.6 & 10.0 \\
\hline \multicolumn{3}{|l|}{ Socioeconomic Status $n(\%)^{b}$} \\
\hline Low & \multicolumn{2}{|c|}{$19(13.8)$} \\
\hline Middle & \multicolumn{2}{|c|}{$56(40.6)$} \\
\hline High & \multicolumn{2}{|c|}{$63(45.7)$} \\
\hline
\end{tabular}

Table 2 shows urinary sodium, potassium, and $\mathrm{Na} / \mathrm{K}$ ratio. The mean urinary $\mathrm{Na} / \mathrm{K}$ ratio was $4.8 \pm 1.8$ of the molar ratio.

Table 2. Urinary sodium, potassium, and $\mathrm{Na} / \mathrm{K}$ ratio of the study participants.

\begin{tabular}{ccc}
\hline Variable & \multicolumn{2}{c}{ Total Sample $(\boldsymbol{n}=\mathbf{1 3 8})$} \\
\cline { 2 - 3 } & Mean & SD \\
\hline Sodium, mmol/L & 154.0 & 44.5 \\
Potassium, mmol/L & 37.8 & 14.0 \\
$\mathrm{Na} / \mathrm{K}$ ratio, molar ratio & 4.8 & 1.8 \\
\hline
\end{tabular}

$\mathrm{Na} / \mathrm{K}$ ratio, sodium-to-potassium ratio; $\mathrm{SD}$, standard deviation.

Table 3 shows the nutritional and dietary intakes. The mean energy intake was $2938 \pm 762 \mathrm{kcal} /$ day, and the mean salt intake was $7.9 \pm 1.4 \mathrm{~g} /$ day. The mean potassium intake was $2475 \pm 188 \mathrm{mg} /$ day. 
Table 3. Nutritional and dietary intakes of the study participants.

\begin{tabular}{ccc}
\hline Variable & \multicolumn{2}{c}{ Total Sample $(\boldsymbol{n}=\mathbf{1 3 8})$} \\
\cline { 2 - 3 } & Mean & SD \\
\hline Nutritional intake & & \\
Energy, kcal/day & 2938 & 762 \\
Protein, g/kg BM & 2.2 & 0.7 \\
Protein, \% of energy & 13.3 & 1.8 \\
Fat, g/kg BM & 2.1 & 0.8 \\
Fat, \% of energy & 27.6 & 5.9 \\
Carbohydrate, g/kg BM & 9.5 & 2.8 \\
Carbohydrate, \% of energy & 57.5 & 7.0 \\
Potassium, mg/day & 2475 & 188 \\
Salt, g/day & 7.9 & 1.4 \\
Dietary intake & & \\
Grains, g/day & 782.1 & 323.1 \\
Potatoes, g/day & 31.6 & 22.5 \\
Vegetables, g/day & 199.4 & 98.0 \\
Fruit, g/day & 176.0 & 164.5 \\
Fishes and shellfishes, g/day & 65.8 & 45.6 \\
Milk and dairy products, g/day & 306.7 & 181.4 \\
Seasoning, g/day & 16.1 & 8.0 \\
\hline
\end{tabular}

BM, body mass; SD, standard deviation.

Figure 1 shows the differences in the mean urinary $\mathrm{Na} / \mathrm{K}$ ratio by SES. The mean urinary $\mathrm{Na} / \mathrm{K}$ ratio (molar ratio) differed by SES in total samples, even if participants were classified into subgroups based on age group. The results were similar.

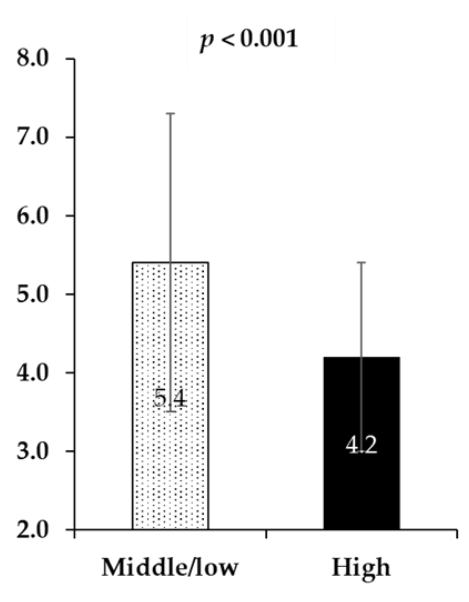

Socioeconomic Status
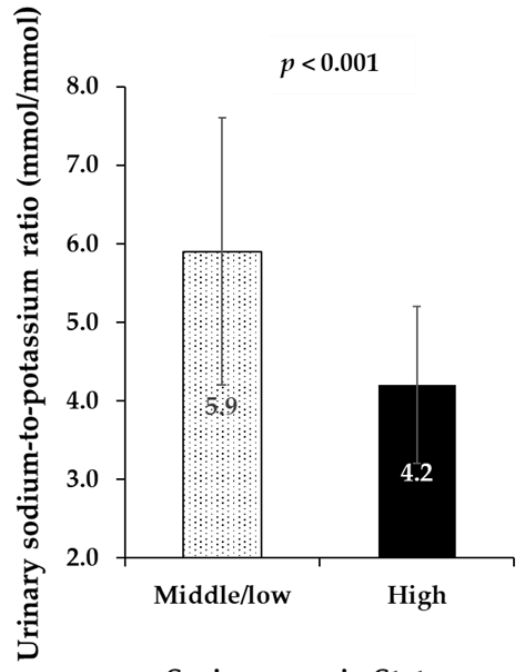

Socioeconomic Status

Age $9-12$ years $(n=50)$

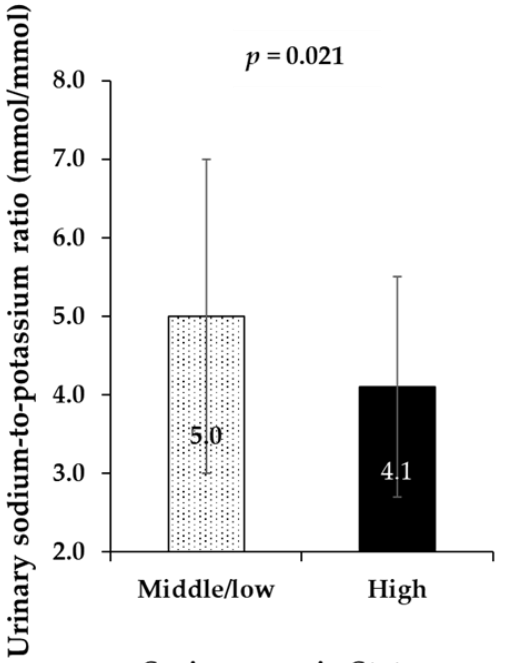

Socioeconomic Status

Age 13-15 years $(n=88)$

Total sample $(\mathrm{n}=\mathbf{1 3 8})$

Figure 1. Differences in the urinary sodium-to-potassium ratio by socioeconomic status. To compare the difference in the mean urinary $\mathrm{Na} / \mathrm{K}$ ratio based on socioeconomic status, one-way analysis of variance was conducted. The socioeconomic status was assessed using the parental educational status, which was classified as follows: low, 11 years or below; middle; $12-15$ years; and high, 16 years or more.

Table 4 shows the associations between SES and urinary $\mathrm{Na} / \mathrm{K}$ ratio based on age group. SES was negatively associated with the urinary $\mathrm{Na} / \mathrm{K}$ ratio in all samples. Even if the participants were classified into subgroups based on the age group, the results were similar. Furthermore, adjustment for the body mass was evaluated, and negative association between SES and the urinary $\mathrm{Na} / \mathrm{K}$ ratio remained significant. 
Table 4. Associations between the socioeconomic status and the urinary $\mathrm{Na} / \mathrm{K}$ ratio by age group.

\begin{tabular}{|c|c|c|c|c|c|c|c|c|c|c|c|c|}
\hline \multirow{3}{*}{ Variable } & \multicolumn{4}{|c|}{ Total Sample $(n=138)$} & \multicolumn{4}{|c|}{ 9-12 Years $(n=50)$} & \multicolumn{4}{|c|}{ 13-15 Years $(n=88)$} \\
\hline & \multicolumn{2}{|c|}{ Unadjusted } & \multicolumn{2}{|c|}{ Adjusted } & \multicolumn{2}{|c|}{ Unadjusted } & \multicolumn{2}{|c|}{ Adjusted } & \multicolumn{2}{|c|}{ Unadjusted } & \multicolumn{2}{|c|}{ Adjusted } \\
\hline & $\beta$ & $p$ & $\beta$ & $p$ & $\beta$ & $p$ & $\beta$ & $p$ & $\beta$ & $p$ & $\beta$ & $p$ \\
\hline \multicolumn{13}{|l|}{$\begin{array}{l}\text { Middle/low }{ }^{\text {a }} \\
\text { (reference) }\end{array}$} \\
\hline High & -0.33 & $<0.001$ & -0.35 & $<0.001$ & -0.51 & $<0.001$ & -0.58 & $<0.001$ & -0.25 & 0.021 & -0.22 & 0.042 \\
\hline & $\begin{array}{l}\mathrm{Na} / \mathrm{K}, \mathrm{s} \\
\text { adjustm } \\
\text { urinary } \\
\text { urinary } \\
\text { using th } \\
\text { and hig. }\end{array}$ & $\begin{array}{l}\text { dium-to } \\
\text { nt for bo } \\
\mathrm{Ja} / \mathrm{K} \text { rati } \\
\mathrm{Ja} / \mathrm{K} \text { rati } \\
\text { parental } \\
16 \text { years }\end{array}$ & $\begin{array}{l}\text { otassiu } \\
\text { mass it } \\
\text { wherea } \\
\text { and the } \\
\text { ducatior } \\
\text { r above }\end{array}$ & $\begin{array}{l}\mathrm{n} \text { ratio; } \beta \\
\text { dex, was } \\
\text { the inde } \\
\text { confounc } \\
\text { al status, }\end{array}$ & $\begin{array}{l}\text {, standar } \\
\text { used to } \\
\text { pendent } \\
\text { ling varia } \\
\text { which ws }\end{array}$ & $\begin{array}{l}\text { dized reg } \\
\text { valuate tl } \\
\text { ariable } \mathrm{w} \\
\text { ble was th } \\
\text { s classifie }\end{array}$ & $\begin{array}{l}\text { ression c } \\
\text { he associ } \\
\text { as socioe } \\
\text { le body n } \\
\text { d as follc }\end{array}$ & $\begin{array}{l}\text { oefficient; } \\
\text { tion of the } \\
\text { conomic s } \\
\text { lass index. } \\
\text { ws: low, } 1\end{array}$ & $\begin{array}{l}\text { a multip } \\
\text { e parenta } \\
\text { tatus; the } \\
\text { a Socioe } \\
1 \text { years or }\end{array}$ & $\begin{array}{l}\text { e regres } \\
\text { educati } \\
\text { depende } \\
\text { onomic } \\
\text { below; 1 }\end{array}$ & $\begin{array}{l}\text { ion anal } \\
\text { hal statu. } \\
\text { ht variabl } \\
\text { tatus was } \\
\text { iddle, } 12\end{array}$ & $\begin{array}{l}\text { sis, witl } \\
\text { with th } \\
\text { e was th } \\
\text { assessec } \\
-15 \text { years }\end{array}$ \\
\hline
\end{tabular}

We examined whether dietary intake differed based on SES. Table 5 shows dietary intake differed with SES by age group. In ages 9-12 years, the items with significantly higher intakes in the high-SES group compared to the low-and-middle-SES group were proteins, lipids, carbohydrates, fruits, milk, and dairy products.

Table 5. Socioeconomic status compared with dietary intake by age group.

\begin{tabular}{|c|c|c|c|c|c|c|c|c|c|c|}
\hline \multirow{4}{*}{ Variable } & \multicolumn{10}{|c|}{ Socioeconomic STATUS $^{\text {a }}$} \\
\hline & \multicolumn{5}{|c|}{ 9-12 Years $(n=50)$} & \multicolumn{5}{|c|}{ 13-15 Years $(n=88)$} \\
\hline & \multicolumn{2}{|c|}{$\begin{array}{l}\text { Low and } \\
\text { Middle }\end{array}$} & \multicolumn{2}{|c|}{ High } & \multirow[t]{2}{*}{$p$} & \multicolumn{2}{|c|}{$\begin{array}{l}\text { Low and } \\
\text { Middle }\end{array}$} & \multicolumn{2}{|c|}{ High } & \multirow[t]{2}{*}{$p$} \\
\hline & Mean & SD & Mean & SD & & Mean & SD & Mean & SD & \\
\hline \multicolumn{11}{|l|}{ Nutritional intake } \\
\hline Energy, kcal/day & 2440.3 & 769.1 & 2608.3 & 592.5 & 0.397 & 3220.3 & 670.5 & 3127.5 & 732.6 & 0.537 \\
\hline Protein, g/kg BM & 2.2 & 0.7 & 2.8 & 0.9 & 0.018 & 1.9 & 0.6 & 2.1 & 0.7 & 0.154 \\
\hline Protein, $\%$ of energy & 13.7 & 1.8 & 14.4 & 1.5 & 0.109 & 12.5 & 1.4 & 13.3 & 2.0 & 0.032 \\
\hline Fat, g/kg BM & 2.1 & 0.6 & 2.8 & 0.9 & 0.001 & 1.7 & 0.7 & 2.0 & 0.7 & 0.148 \\
\hline Fat, \% of energy & 29.3 & 4.4 & 32.3 & 5.0 & 0.026 & 24.9 & 5.6 & 27.2 & 5.9 & 0.073 \\
\hline Carbohydrate, g/kg BM & 9.2 & 3.0 & 9.9 & 2.7 & 0.410 & 9.5 & 3.0 & 9.3 & 2.6 & 0.736 \\
\hline Carbohydrate, $\%$ of energy & 55.4 & 5.2 & 52.1 & 5.3 & 0.028 & 60.8 & 6.3 & 58.0 & 7.4 & 0.066 \\
\hline Potassium, mg/day & 2498.8 & 189.4 & 2469.9 & 191.0 & 0.595 & 2446.8 & 186.3 & 2496.7 & 188.4 & 0.217 \\
\hline Salt, g/day & 7.5 & 1.1 & 7.0 & 1.6 & 0.249 & 8.5 & 1.3 & 7.9 & 1.3 & 0.041 \\
\hline \multicolumn{11}{|l|}{ Dietary intake } \\
\hline Grains, g/day & 607.1 & 256.9 & 521.7 & 175.3 & 0.183 & 949.7 & 288.3 & 848.5 & 323.8 & 0.125 \\
\hline Potatoes, g/day & 30.6 & 22.8 & 40.8 & 31.0 & 0.186 & 26.7 & 16.2 & 32.7 & 22.1 & 0.145 \\
\hline Vegetables, g/day & 155.4 & 77.6 & 194.5 & 79.9 & 0.086 & 200.6 & 95.2 & 230.4 & 113.5 & 0.185 \\
\hline Fruit, g/day & 99.2 & 70.9 & 178.0 & 132.6 & 0.010 & 182.9 & 168.4 & 223.9 & 201.6 & 0.301 \\
\hline Fishes and shellfishes, g/day & 58.7 & 33.9 & 68.6 & 31.3 & 0.292 & 69.1 & 36.0 & 65.1 & 49.9 & 0.668 \\
\hline Milk and dairy products, $\mathrm{g}$ /day & 263.0 & 144.9 & 391.8 & 207.2 & 0.013 & 259.4 & 160.1 & 343.9 & 191.7 & 0.027 \\
\hline Seasoning, g/day & 13.6 & 5.5 & 16.5 & 7.8 & 0.144 & 17.5 & 9.0 & 16.0 & 8.7 & 0.426 \\
\hline
\end{tabular}

BM, body mass; BMI, body mass index; SD, standard deviation; the difference in the mean dietary intake according to SES was compared using one-way analysis of variance. ${ }^{\text {a }}$ Socioeconomic status was assessed using the parental educational status, which was classified as follows: low, 11 years or below; middle, 12-15 years; and high, 16 years or above.

In ages 13-15 years, the items with significantly higher intakes in the high-SES group compared to the low-and-middle-SES group were proteins, milk and dairy products, with significantly lower salt intakes in the high-SES group compared to the low-and-middleSES group. The common denominator between 9-12 and 13-15 years was "milk and dairy products".

We investigated whether dietary intake was associated with urinary $\mathrm{Na} / \mathrm{K}$ ratio. Table 6 shows the multiple regression model of urinary $\mathrm{Na} / \mathrm{K}$ ratio by age group. Fruit and milk and dairy products were significantly negatively associated with the urinary 
$\mathrm{Na} / \mathrm{K}$ ratio in the single regression analysis between ages 9-12 and 13-15 years (Model 1). These variables were added for adjustments of BMI, and their associations were evaluated (Model 2). After adjustment, fruit and milk and dairy products were still associated with the urinary $\mathrm{Na} / \mathrm{K}$ ratio in the adjusted model among ages 9-12 and 13-15 years. Further, these variables were added for adjustments of SES, and their associations were evaluated (Model 3). Milk and dairy products were still associated with the urinary $\mathrm{Na} / \mathrm{K}$ ratio in the adjusted model for ages 13-15 and 9-12 years (Model 3). Although fruits were associated with the urinary $\mathrm{Na} / \mathrm{k}$ ratio in the adjusted model for ages $13-15$ years, their association disappeared in ages $9-12$ years.

Table 6. Associations between dietary intake and the urinary $\mathrm{Na} / \mathrm{K}$ ratio by age group.

\begin{tabular}{|c|c|c|c|c|c|c|c|c|c|c|c|c|}
\hline \multirow{4}{*}{ Variable } & \multicolumn{12}{|c|}{ Urinary Na/K Ratio } \\
\hline & \multicolumn{6}{|c|}{ 9-12 Years $(n=50)$} & \multicolumn{6}{|c|}{ 13-15 Years $(n=88)$} \\
\hline & \multicolumn{2}{|c|}{ Model 1} & \multicolumn{2}{|c|}{ Model 2} & \multicolumn{2}{|c|}{ Model 3} & \multicolumn{2}{|c|}{ Model 1} & \multicolumn{2}{|c|}{ Model 2} & \multicolumn{2}{|c|}{ Model 3} \\
\hline & $\beta$ & $P$ & $\beta$ & $P$ & $\beta$ & $P$ & $\beta$ & $P$ & $\beta$ & $P$ & $\beta$ & $P$ \\
\hline \multicolumn{13}{|l|}{ Dietary intake } \\
\hline Grains, g/day & -0.14 & 0.315 & & & & & -0.12 & 0.246 & & & & \\
\hline Potatoes, g/day & -0.21 & 0.152 & & & & & -0.12 & 0.279 & & & & \\
\hline Vegetables, g/day & -0.18 & 0.219 & & & & & -0.12 & 0.272 & & & & \\
\hline Fruit, g/day & -0.40 & 0.004 & -0.40 & 0.004 & -0.22 & 0.078 & -0.22 & 0.007 & -0.26 & 0.016 & -0.25 & 0.018 \\
\hline Fishes and shellfishes, g/day & -0.05 & 0.749 & & & & & 0.02 & 0.820 & & & & \\
\hline Milk and dairy products, g/day & -0.57 & $<0.001$ & -0.56 & $<0.001$ & -0.35 & $<0.001$ & -0.35 & 0.001 & -0.35 & 0.001 & -0.31 & 0.003 \\
\hline Seasoning, g/day & -0.14 & 0.332 & & & & & 0.08 & 0.458 & & & & \\
\hline
\end{tabular}

$\beta$, standardized regression coefficient; BMI, body mass index; $\mathrm{Na} / \mathrm{K}$, sodium-to-potassium ratio; SES, socioeconomic status, SES was assessed using the parental educational status, which was classified as follows: low 11 years or below; middle, 12-15 years; and high, 16 years or more. Multiple regression, with adjustment for potential confounding factors, was used to evaluate the association in dietary intake with the urinary $\mathrm{Na} / \mathrm{K}$ ratio; the dependent variable was the urinary $\mathrm{Na} / \mathrm{K}$ ratio, and the independent variable was dietary intake; the independent variable selection was calculated using a stepwise method, and confounding variables were BMI and SES; Model 1, unadjusted model; Model 2, a model adjusted for BMI; and Model 3, a model adjusted for BMI and SES.

No differences were observed in the dietary intake associated with the urinary $\mathrm{Na} / \mathrm{K}$ ratio between age groups, and the effect of SES was different in age groups.

\section{Discussion}

\subsection{Association between SES and the Urinary Na/K Ratio}

In this study, the mean urinary $\mathrm{Na} / \mathrm{K}$ molar ratio was 4.8 in Japanese male adolescent and child football players, which is well above the recommended value of 1.5 , considered to be beneficial for health by the World Health Organization $[31,32]$. The urinary N/K ratio in children (5.2) was higher than that in adolescents (4.6) (data not shown). High urinary $\mathrm{Na} / \mathrm{K}$ ratios (about three times the 1 molar ratio) were found in Japanese child soccer players; therefore, our results suggested that poor dietary habits have started in early childhood.

Our results suggested that differences in the urinary $\mathrm{Na} / \mathrm{K}$ ratio of SES in Japanese male adolescent and child football players. Furthermore, higher SES was independently negatively associated with the spot urine $\mathrm{Na} / \mathrm{K}$ ratio. Two previous studies in young people reported that the considered associations between SES and urinary electrolyte excretion in Australian children [16] and Korean young adults [33] were positively associated with urinary sodium. Although the item in this study was different from that of previous studies, the results of the current study in Japanese adolescent and child football players were consistent with these findings, suggesting that SES influences the urinary $\mathrm{Na} / \mathrm{K}$ ratio even in adolescents. SES disparities in adult food choices were likely related to high-salt foods and high-potassium foods, which may filter down into the children's eating practices. Higher protein intake may influence kidney function [34] and was also associated with higher salt intake [16]. The diet of Japanese male adolescent and child football players was considered to need improvement. The salt intake in the low-and-middle-SES group 
in our cohort was $0.5 \mathrm{~g} /$ day higher than in the high-SES group in children (Table 5). This was similar to a study of Australian children [35]. Further, high potassium intake (milk and dairy products and fruit) also differed based on SES. From those, the present study results showed that SES disparities in adult food choices associated with high-salt foods and high-potassium foods may filter into children's eating practices. The health outcome in adolescents was influenced by SES.

\subsection{The Food Groups Associated with Urinary Na/K Ratio and the Effects of SES}

Our results showed that consumption of fruits and milk and dairy products was significantly inversely associated with the urinary $\mathrm{Na} / \mathrm{K}$ ratio in Japanese adolescent and child football players. Some previous studies reported that the dietary source of potassium was milk and dairy products $[7,16,36,37]$ and fruits $[38,39]$ among adolescents and children. Based on these findings, we considered that our results were reasonable.

In children and adolescents, milk and dairy product intake differed based on SES. A previous study reported that milk and dairy product consumption has been associated with soft drinks, SES, gender, age group, eating behavior, and nutritional status [40]. Our results supported that of a previous study.

However, a significant inverse association between milk and dairy products and the urinary $\mathrm{Na} / \mathrm{K}$ ratio was independent of SES. We found that milk and dairy product consumption lowers the urinary $\mathrm{Na} / \mathrm{K}$ ratio in children and adolescents independently of SES. Although the reason remains unclear at this time, with an affecting factor other than SES. In Japan, most elementary and junior high school lunch provides $200 \mathrm{~mL}$ of milk daily. Based on the results of the National Health and Nutrition Examination Survey (2020) [38], the mean intake of milk and dairy products was $304.6 \mathrm{~g} /$ day in ages 7-14 years, with results much higher than the intake per capita of $132.2 \mathrm{~g}$ nationwide. Moreover, our results in football players were $306.7 \mathrm{~g} /$ day, which was similar to that of children and adolescents of the same generation, so the intake of milk and dairy products of study participants is not particularly high. Consequently, the intake of milk and dairy product may be affected by school lunches.

When we analyzed the results by considering the effects of SES, no association was observed between the fruit intake and urinary $\mathrm{Na} / \mathrm{K}$ ratio in children. Previous studies have reported that multiple factors, such as knowledge, preferences, eating habits, and food environment, are associated with fruit intake in children [41,42], which was the factor most strongly associated with household availability and associated with purchasing power [43]. The present study results also suggested that SES differences in children indicate a significant difference in fruit intakes (Table 5). Fruits are low in energy density and are expensive for households with a limited budget. Consequently, we considered that SES differences were related to the purchasing power and household availability of fruits, which in turn affected children's fruit intake.

However, we analyzed the results by considering the effects of SES in adolescents, and, with the remaining association between fruit intake and urinary $\mathrm{Na} / \mathrm{K}$ ratio, this result was different from that of the children's result. As children transition into adolescence, influences often decrease due to competing influences from other social settings [44], and often adolescence increased the autonomy over their food choices compared with children [45]. The present study result was also not significantly different in fruit intake based on SES (Table 5). From these findings, we consider that our results may have an affecting factor other than SES in adolescents (e.g., increased autonomy over their food choices and decreased family influences) which was associated with increased intake of fruit and decreased urinary $\mathrm{Na} / \mathrm{K}$ ratio. Further studies of fruit intake in adolescents and children are needed to clarify this issue.

For the first time, the results of this study indicate that the urinary $\mathrm{Na} / \mathrm{K}$ ratio in child football players was high, and poor dietary habits have started during childhood. Further, the results showed that socioeconomic disparities were observed in the urinary $\mathrm{Na} / \mathrm{K}$ ratio in Japanese adolescents and children. Although no differences were observed in the food 
groups associated with urinary $\mathrm{Na} / \mathrm{K}$ ratio based on age group, milk and dairy product and fruit intakes are associated with the urinary $\mathrm{Na} / \mathrm{K}$ ratio, showing different effects of SES by age group. In due consideration of the fact that rapidly increasing SES is quite difficult, nutritional education to children and adolescents and their parents may have real power to affect the urinary $\mathrm{Na} / \mathrm{K}$ ratio. Therefore, nutritional education to decrease salt intake and increase intake of milk and dairy products and fruits should be provided to adolescent and child football players and their parents.

The strength of this study was the use of reliable urine samples, the use of dietary intake calculation using a validated questionnaire, and measuring the anthropometric data of children and adolescent football players.

This study has a few limitations. Its cross-sectional nature did not permit the assessment of causality. In the future, intervention studies are warranted to clarify whether there is a change in the urinary $\mathrm{Na} / \mathrm{K}$ ratio with increased milk and dairy products and fruit intakes. In the present study, only 138 participants were included, which is a relatively small sample size. In addition, none of the participants could be considered representatives of the general Japanese adolescent and child football players, thereby making generalizations difficult. Future research should focus on recruiting a large number of subjects, including female football players, to increase the sample size. Furthermore, to increase generalizability of the results, it is imperative to have a larger sample size representative of the population of Japanese adolescents and children. The SES was classified into three categories using the occupational classification in the analysis, which was reorganized into two classifications, and classification might change the associations. Fruit intake is affected by seasonal fluctuations [46]. The wholesale volume of fruits in December is the second-highest after November, and the wholesale price is reported to be the lowest of the year [47]. Therefore, the association between fruits and the urinary $\mathrm{Na} / \mathrm{K}$ ratio in this study may be slightly overestimated. Furthermore, to eliminate the effects of physical activity on the urinary $\mathrm{Na} / \mathrm{K}$ ratio, only football players with a high level of physical activity were included in this study. Moreover, urine collections were held during weekend practice or when matches were not scheduled. However, the effects of physical activity and sodium loss due to sweating could not be completely excluded. Notwithstanding, since this study was conducted in December, decreased sodium levels due to sweating would not have a significant effect on the results. Diurnal variations were observed in the amount of sodium and potassium excretion [48]. Although urinary potassium concentration depends on aldosterone concentration, in this study its effect has not been excluded [49]. Hence, further studies are needed to consider the effects of these confounding factors. The result of urinary $\mathrm{Na} / \mathrm{K}$ ratio depends on the moment of urine sample collection; thus, the timing of spot urine was morning in this study. Even if the urine is first thing in the morning, the collection time and whether it is fasting or not will affect the urine $\mathrm{Na} / \mathrm{K}$ ratio, since the effects of collection time and fasting were not considered. Lastly, the dietary assessment used a dietary assessment questionnaire (i.e., DHQ), and sodium consumption as a sports supplement, or a drink, represents a residual confound that may change the association observed in this study. Furthermore, we could not exclude residual confounding from unmeasured or unknown factors.

\section{Conclusions}

The results of this study suggested that the urinary $\mathrm{Na} / \mathrm{K}$ ratios in Japanese child football players were high due to poor diets during childhood. Further, higher SES is associated with lower urinary $\mathrm{Na} / \mathrm{K}$ ratio in Japanese adolescent and child football players.

Furthermore, milk and dairy products and fruit intake are associated with the urinary $\mathrm{Na} / \mathrm{K}$ ratio, showing different effects of SES by age group and no differences in food groups. Thus, nutritional education to decrease salt intake and increase intake of milk dairy products and fruits should be provided to adolescent and child football players and their parents. 


\begin{abstract}
Author Contributions: Conceptualization, Y.N., A.H. and M.M.; methodology, Y.N. and A.M.; software, Y.N.; formal analysis, Y.N., A.H. and M.M.; investigation, Y.N., A.M. and M.M.; writingoriginal draft preparation, Y.N., A.H. and M.M.; writing-editing, Y.N., A.H. and M.M.; supervision, A.H. and M.M.; project administration, Y.N. and M.M.; funding acquisition, A.H. and M.M. All authors have read and agreed to the published version of the manuscript.
\end{abstract}

Funding: This research received no external funding.

Institutional Review Board Statement: The present study was conducted following the guidelines of the Declaration of Helsinki and approved by the Ethics Committee of Musashigaoka Junior college, Japan (No. 20-3).

Informed Consent Statement: Informed consent was obtained from all participant and their parents involved in the study.

Data Availability Statement: Data presented in this study are available upon request from the corresponding author. Data are not publicly available as they contain private information of the participants.

Acknowledgments: The authors are deeply grateful to the study participants, their parents, and the football team staff for their cooperation.

Conflicts of Interest: The authors declare no conflict of interest.

\title{
References
}

1. Aburto, N.J.; Hanson, S.; Gutierrez, H.; Hooper, L.; Elliott, P.; Cappuccio, F.P. Effect of increased potassium intake on cardiovascular risk factors and disease: Systematic review and meta-analyses. BMJ 2013, 346, f1378. [CrossRef]

2. Aburto, N.J.; Ziolkovska, A.; Hooper, L.; Elliott, P.; Cappuccio, F.P.; Meerpohl, J.J. Effect of lower sodium intake on health: Systematic review and meta-analyses. BMJ 2013, 346, f1326. [CrossRef] [PubMed]

3. Aaron, K.J.; Sanders, P.W. Role of dietary salt and potassium intake in cardiovascular health and disease: A review of the evidence. Mayo Clin. Proc. 2013, 88, 987-995. [CrossRef] [PubMed]

4. Strazzullo, P.; D’Elia, L.; Kandala, N.; Cappuccio, F.P. Salt intake, stroke, and cardiovascular disease: Meta-analysis of prospective studies. BMJ 2009, 339, b4567. [CrossRef] [PubMed]

5. Tabara, Y.; Takahashi, Y.; Kumagai, K.; Setoh, K.; Kawaguchi, T.; Takahashi, M.; Muraoka, Y.; Tsujikawa, A.; Gotoh, N.; Terao, C.; et al. Descriptive epidemiology of spot urine sodium-to-potassium ratio clarified close relationship with blood pressure level: The Nagahama study. J. Hypertens. 2015, 33, 2407-2413. [CrossRef]

6. Okuda, M.; Asakura, K.; Sasaki, S.; Shinozaki, K. Twenty-four-hour urinary sodium and potassium excretion and associated factors in Japanese secondary school students. Hypertens. Res. 2016, 39, 524-529. [CrossRef] [PubMed]

7. Nagashima, Y.; Horikawa, A.; Mori, M. Association between $24 \mathrm{~h}$ urinary sodium and potassium excretion and dietary intake in Japanese male adolescent football players. Adolescents 2021, 1, 461-472. [CrossRef]

8. Shi, L.; Krupp, D.; Remer, T. Salt, fruit and vegetable consumption and blood pressure development: A longitudinal investigation in healthy children. Br. J. Nutr. 2014, 111, 662-671. [CrossRef]

9. Ji, C.; Kandala, N.; Cappuccio, F.P. Cappuccio FPSpatial variation of salt intake in Britain and association with socioeconomic statusBMJ Open. BMJ Open 2013, 3, e002246. [CrossRef]

10. Miyaki, K.; Song, Y.; Taneichi, S.; Tsutsumi, A.; Hashimoto, H.; Kawakami, N.; Takahashi, M.; Shimazu, A.; Inoue, A.; Kurioka, S.; et al. Socioeconomic status is significantly associated with dietary salt intakes and blood pressure in Japanese workers (J-HOPE Study). Int. J. Environ. Res. Public Health 2013, 10, 980-993. [CrossRef]

11. Hong, J.W.; Noh, J.H.; Kim, D.J. Factors associated with high sodium intake based on estimated 24-hour urinary sodium excretion: The 2009-11 Korea national health and nutrition examination survey. Medicine 2016, 95, e2864. [CrossRef] [PubMed]

12. Chien, K.L.; Hsu, H.C.; Chen, P.C.; Su, T.C.; Chang, W.T.; Chen, M.F.; Lee, Y.T. Urinary sodium and potassium excretion and risk of hypertension in Chinese: Report from a community-based cohort study in Taiwan. J. Hypertens. 2008, 26, 1750-1756. [CrossRef] [PubMed]

13. Huang, Y.; Van Horn, L.; Tinker, L.F.; Neuhouser, M.L.; Carbone, L.; Mossavar-Rahmani, Y.; Thomas, F.; Prentice, R.L. Measurement error corrected sodium and potassium intake estimation using 24-hour urinary excretion. Hypertension 2014, 63, 238-244. [CrossRef] [PubMed]

14. Lucko, A.M.; Doktorchik, C.; Woodward, M.; Cogswell, M.; Neal, B.; Rabi, D.; Anderson, C.; He, F.J.; MacGregor, G.A.; L'Abbe, M.L.; et al. Percentage of Ingested sodium excreted in 24-hour urine collections: A systematic review and me-ta-analysis. J. Clin. Hypertens. 2018, 20, 1220-1229. [CrossRef]

15. Iwahori, T.; Ueshima, H.; Miyagawa, N.; Ohgami, N.; Yamashita, H.; Ohkubo, T.; Murakami, Y.; Shiga, T.; Miura, K. Six random specimens of daytime casual urine on different days are sufficient to estimate daily sodium/potassium ratio in comparison to 7-day 24-h urine collections. Hypertens. Res. 2014, 37, 765-771. [CrossRef] 
16. Grimes, C.A.; Riddell, L.J.; Campbell, K.J.; Beckford, K.; Baxter, J.R.; He, F.J.; Nowson, C.A. Dietary intake and sources of sodium and potassium among Australian schoolchildren: Results from the cross-sectional salt and other nutrients in children (SONIC) Study. BMJ Open 2017, 7, e016639. [CrossRef]

17. Seko, C.; Taguchi, Y.; Segawa, H.; Odani, K.; Aoi, W.; Wada, S.; Kitaoka, K.; Masumoto, T.; Higashi, A. Estimation of salt intake and sodium-to-potassium ratios assessed by urinary excretion among Japanese elementary school children. Clin. Exp. Hypertens. 2018, 40, 481-486. [CrossRef]

18. De Mestral, C.; Mayén, A.L.; Petrovic, D.; Marques-Vidal, P.; Bochud, M.; Stringhini, S. Socioeconomic determinants of sodium intake in adult populations of high-income countries: A systematic review and meta-analysis. Am. J. Public Health 2017, 107, e1-e12. [CrossRef]

19. Miyagawa, N.; Okuda, N.; Nakagawa, H.; Takezaki, T.; Nishi, N.; Takashima, N.; Fujiyoshi, A.; Ohkubo, T.; Kadota, A.; Okamura, T.; et al. Socioeconomic status associated with urinary sodium and potassium excretion in Japan: NIPPON DATA2010. J. Epidemiol. 2018, 28 (Suppl. 3), S29-S34. [CrossRef]

20. Yamashita, M.; Tabara, Y.; Higo, Y.; Setoh, K.; Kawaguchi, T.; Takahashi, Y.; Kosugi, S.; Nakayama, T.; Matsuda, F.; Wakamura, T.; et al. Association between socioeconomic factors and urinary sodium-to-potassium ratio: The Nagahama Study. Hypertens. Res. 2018, 41, 973-980. [CrossRef]

21. Haff, G.G.; Triplett, N.T. Essentials of Strength Training and Conditioning, 4th ed.; Human Kinetics Publishers: Champaign, IL, USA, 2015

22. Ambrosini, G.L.; Oddy, W.H.; Robinson, M.; O’Sullivan, T.A.; Hands, B.P.; de Klerk, N.H.; Silburn, S.R.; Zubrick, S.R.; Kendall, G.E.; Stanley, F.J.; et al. Adolescent Dietary Patterns Are Associated with Lifestyle and Family Psychosocial Factors. Public Health Nutr. 2016, 19, 765. [CrossRef]

23. The International Standard Classification of Education 2011 (ISCED). Available online: http://uis.unesco.org/en/topic/ international-standard-classification-education-isced (accessed on 11 December 2021).

24. Uechi, K.; Asakura, K.; Ri, Y.; Masayasu, S.; Sasaki, S. Advantage of multiple spot urine collections for estimating daily sodium excretion: Comparison with two 24-h urine collections as reference. J. Hypertens. 2016, 34, 204-214. [CrossRef] [PubMed]

25. Sasaki, S.; Yanagibori, R.; Amano, K. Self-Administered Diet History Questionnaire developed for health education: A relative validation of the test-version by comparison with 3-day diet record in women. J. Epidemiol. 1998, 8, 203-215. [CrossRef]

26. Sasaki, S.; Yanagibori, R.; Amano, K. Validity of a Self-Administered Diet History Questionnaire for assessment of sodium and potassium: Comparison with single 24-hour urinary excretion. Jpn. Circ. J. 1998, 62, 431-435. [CrossRef]

27. Kobayashi, S.; Honda, S.; Murakami, K.; Sasaki, S.; Okubo, H.; Hirota, N.; Notsu, A.; Fukui, M.; Date, C. Both comprehensive and brief self-administered diet history questionnaires satisfactorily rank nutrient intakes in Japanese adults. J. Epidemiol. 2012, 22, 151-159. [CrossRef] [PubMed]

28. Science and Technology Agency. Standard Tables of Food Composition in Japan; 5th Revised and Enlarged; Printing Bureau of the Ministry of Finance: Tokyo, Japan, 2005. (In Japanese)

29. Nagashima, Y.; Horikawa, A.; Koita, A.; Miyaki, M.; Iguchi, M.; Tanaka, A. Validity and reproducibility of a self-administered diet history questionnaire (dhq) answered by junior athletes and their mothers. Jpn. J. Sports Nutr. 2020, 13, 25-39.

30. Ministry of Health, Labour and Welfare. Basic Survey on Wage Structure. Available online: https://www.mhlw.go.jp/toukei/ itiran/roudou/chingin/kouzou/z2020/index.html (accessed on 17 December 2021).

31. WHO. Potassium Intake for Adults and Children. Available online: https://www.who.int/publications/i/item/9789241504829 (accessed on 17 December 2021).

32. WHO. Diet, Nutrition and the Prevention of Chronic Diseases; Report of a Joint WHO/FAO Expert Consultation; World Health Organization: Geneva, Switzerland, 2003; Volume 916, pp. 1-149. Available online: http://whqlibdoc.who.int/trs/WHO_TRS_ 916.pdf (accessed on 28 October 2021).

33. Suh, S.H.; Song, S.H.; Choi, H.S.; Kim, C.S.; Bae, E.H.; Ma, S.K.; Kim, S.W. Parental educational status independently predicts the risk of prevalent hypertension in young adults. Sci. Rep. 2021, 11, 3698. [CrossRef]

34. Schwingshackl, L.; Hoffmann, G. Comparison of High vs. Normal/Low Protein Diets on Renal Function in Subjects without Chronic Kidney Disease: A Systematic Review and Meta-Analysis. PLoS ONE 2014, 9, e97656. [CrossRef]

35. Grimes, C.A.; Campbell, K.J.; Riddell, L.J.; Nowson, C.A. Is socioeconomic status associated with dietary sodium intake in Aus-tralian children? A cross-sectional studyBMJ Open. BMJ Open 2013, 3, e002106.

36. Gonçalves, C.; Abreu, S.; Padrão, P.; Pinho, O.; Graça, P.; Breda, J.; Santos, R.; Moreira, P. Sodium and potassium urinary excretion and dietary intake: A cross-sectional analysis in adolescents. Food Nutr. Res. 2016, 60, 29442. [CrossRef]

37. Webster, J.L.; Dunford, E.K.; Neal, B.C. A systematic survey of the sodium contents of processed foods. Am. J. Clin. Nutr. 2010, 91, 413-420. [CrossRef]

38. Ministry of Health, Labour and Welfare. The National Health and Nutrition Survey Japan. 2020. Available online: www.mhlw.go.jp/ stf/seisakunitsuite/bunya/kenkou_iryou/kenkou/eiyou/r1-houkoku_00002.html (accessed on 12 February 2022).

39. Turin, T.C.; Okuda, N.; Miura, K.; Nakamura, Y.; Rumana, N.; Ueshima, H.; Nippon DATA80/90 Research Group. Dietary intake of potassium and associated dietary factors among representative samples of Japanese general population: NIPPON DATA 80/90. J. Epidemiol. 2010, 20 (Suppl. 3), S567-S575. [CrossRef] [PubMed]

40. Moreno, L.A.; Bel-Serrat, S.; Santaliestra-Pasías, A.; Bueno, G. Dairy products, yogurt consumption, and cardiometabolic risk in children and adolescents, Nutrition Reviews. Nutr. Rev. 2015, 73 (Suppl. 1), 8-14. [CrossRef] [PubMed] 
41. Fitzgerald, A.; Heary, C.; Nixon, E.; Kelly, C. Factors influencing the food choices of Irish children and adolescents: A qualitative investigation. Health Promot. Int. 2010, 25, 289-298. [CrossRef] [PubMed]

42. Dror, D.K.; Allen, L.H. Dairy product intake in children and adolescents in developed countries: Trends, nutritional contribution, and a review of association with health outcomes. Nutr. Rev. 2014, 72, 68-81. [CrossRef]

43. Rasmussen, M.; Krølner, R.; Klepp, K.I.; Lytle, L.; Brug, J.; Bere, E.; Due, P. Determinants of fruit and vegetable consumption among children and adolescents: A review of the literature. Part I: Quantitative studies. Int. J. Behav. Nutr. Phys. Act. 2006, 3, 22.

44. Institute of Medicine. (US) Committee on Capitalizing on Social Science and Behavioral Research to Improve the Public's health. In Promoting Health: Intervention Strategies from Social and Behavioral Research; PAPER CONTRIBUTION E, Preadolescent and Adolescent Influences on Health; Smedley, B.D., Syme, S.L., Eds.; National Academies Press: Washington, DC, USA, 2000. Available online: https: / www.ncbi.nlm.nih.gov/books/NBK222829 / (accessed on 12 February 2022).

45. Pearson, N.; Biddle, S.J.; Gorely, T. Family correlates of fruit and vegetable consumption in children and adolescents: A systematic review. Public Health Nutr. 2009, 12, 267-283. [CrossRef]

46. Fahey, M.T.; Sasaki, S.; Kobayashi, M.; Akabane, M.; Tsugane, S. Seasonal misclassification error and magnitude of true betweenperson variation in dietary nutrient intake: A random coefficients analysis and implications for the Japan Public Health Center (JPHC) Cohort Study. Public Health Nutr. 2003, 6, 385-391, Erratum in: Public Health Nutr. 2003, 6, 521. [CrossRef]

47. Ministry of Agriculture, Forestry and Fisheries. Report on the Survey of Wholesale Market of Fruits and Vegetables in 2020 Available online: https://www.maff.go.jp/j/tokei/kouhyou/seika_orosi/\#s (accessed on 17 December 2021).

48. Van der Horst, K.; Oenema, A.; Ferreira, I.; Wendel-Vos, W.; Giskes, K.; van Lenthe, F.; Brug, J. A systematic review of environmental correlates of obesity-related dietary behaviors in youth. Health Educ. Res. 2007, 22, 203-226. [CrossRef]

49. Rakova, N.; Jüttner, K.; Dahlmann, A.; Schröder, A.; Linz, P.; Kopp, C.; Rauh, M.; Goller, U.; Beck, L.; Agureev, A.; et al. Long-Term Space Flight Simulation Reveals Infradian Rhythmicity in Human Na+ Balance. Cell Metab. 2013, 17, 125-131. [CrossRef] 